\title{
TIMBULAN SAMPAH B3 RUMAHTANGGA DAN POTENSI DAMPAK KESEHATAN LINGKUNGAN DI KABUPATEN SLEMAN, YOGYAKARTA (Generation of Household Hazardous Solid Waste and Potential Impacts on Environmental Health in Sleman Regency, Yogyakarta)
}

\author{
Iswanto ${ }^{1, *}$ Sudarmadji ${ }^{2}$, Endang Tri Wahyuni ${ }^{3}$ dan Adi Heru Sutomo ${ }^{4}$ \\ ${ }^{1}$ Jurusan Kesehatan Lingkungan, Politeknik Kesehatan Kementerian Kesehatan Yogyakarta, \\ Jl. Tatabumi no.3, Banyuraden, Gamping, Sleman 55293. \\ ${ }^{2}$ Departemen Geografi dan Ilmu Lingkungan, Fakultas Geografi, Universitas Gadjah Mada, \\ Sekip Utara, Yogyakarta, 55281. \\ ${ }^{3}$ Departemen Kimia, Fakultas MIPA Universitas Gadjah Mada, Sekip Utara, Yogyakarta, 55281 \\ ${ }^{4}$ Program Studi Pendidikan Dokter, Fakultas Kedokteran, Universitas Gadjah Mada, \\ Sekip Utara, Yogyakarta, 55281.
}

*Penulis korespondensi. Tel/Fax : 0274-560962. Email: isswanto@yahoo.com.

Diterima: 8 Oktober 2015

Disetujui: 13 Januari 2016

\begin{abstract}
Abstrak
Sampah rumahtangga yang mengandung Bahan Berbahaya dan Beracun (B3) seperti baterai, lampu listrik, elektronik, kemasan pestisida, pemutih pakaian, pembersih lantai, cat, kaleng bertekanan (aerosol), sisa obat-obatan, termometer dan jarum suntik berpotensi mengancam kesehatan manusia dan lingkungan. Meskipun kuantitas sampah B3 rumahtangga (SB3-RT) di Kabupaten Sleman hanya 2,44 g/orang/hari atau sekitar 0,488\% dari sampah domestik, tetapi karena memiliki karakteristik mudah meledak, mudah terbakar, reaktif, beracun, infeksius dan/atau korosif maka sangat membahayakan bagi kesehatan dan lingkungan (air, tanah, udara). Sampai saat ini, SB3-RT di Kabupaten Sleman masih ditangani seperti layaknya sampah domestik, yaitu dibakar, dibuang ke sungai, ditimbun di pekarangan, dibuang ke tempat pembuangan sampah ilegal atau dibuang ke Tempat Pemrosesan Akhir (TPA) Piyungan. Jenis SB3-RT yang banyak ditemukan adalah sampah elektronik (24,91\%), lampu listrik bekas (18,08\%) dan baterai bekas (16,71\%). Ketiga jenis sampah tersebut mengandung berbagai unsur logam berat seperti $\mathrm{Cd}, \mathrm{Pb}, \mathrm{Hg}, \mathrm{Cr}, \mathrm{As}, \mathrm{Ni}, \mathrm{Co}, \mathrm{Zn}, \mathrm{Cu}, \mathrm{Al}, \mathrm{Mn}, \mathrm{Li}, \mathrm{Sb}$ dan Fe yang umumnya bersifat toksik, karsinogenik dan akumulatif yang dapat masuk ke dalam tubuh manusia secara langsung atau melalui rantai makanan. Pemaparan bahan berbahaya beracun (B3) dapat menyebabkan kerusakan pada berbagai jaringan/organ tubuh pada masyarakat sekitar tempat pembuangan, petugas sampah, pemulung, pengepul, pemanfaat dan pelaku daur ulang SB3-RT. Oleh karena itu SB3-RT perlu dikelola sebagaimana mestinya sesuai dengan sifat dan karakteristiknya.
\end{abstract}

Kata kunci: bahan berbahaya beracun, dampak, kesehatan lingkungan, sampah.

\begin{abstract}
Household solid waste containing hazardous and toxic materials such as batteries, electric light, electronics, pesticides, bleach, cleaner, paint, pressurized cans (aerosol), unused medicines, thermometers and syringes can threaten human and environment. Although the quantity of Household Hazardous Solid Waste (HHSW) in Sleman Regency only $2.44 \mathrm{~g} /$ person/day or approximately $0.49 \%$ of domestic waste, but because it has the characteristics of explosive, flammable, reactive, toxic, infectious and/or corrosive then potentially cause health and environmental issues (water, soil, air) seriously. Until now, HHSW in Sleman still handled like domestic waste, which is burned, dumped into the river, dumped in the yard, disposed into illegal dumping or dumped into the final disposal site (TPA Piyungan). Types of HHSW most common are electronic waste (24.91\%), electric lamps former (18.08\%) and used batteries (16.71\%). Those HHSW contain a variety of heavy metals such as $\mathrm{Cd}, \mathrm{Pb}, \mathrm{Hg}, \mathrm{Cr}, \mathrm{As}, \mathrm{Ni}, \mathrm{Co}, \mathrm{Zn}, \mathrm{Cu}, \mathrm{Al}, \mathrm{Mn}, \mathrm{Li}$, Sb and Fe, which are generally toxic, carcinogenic and bioaccumulative that can be entered into the human body directly or through the food chain. Exposure to harmful and toxic materials can cause damage to various tissues/organs of the communities around the dumping, garbage worker, scavengers, collectors, users and recycler of HHSW. Therefore HHSW in Sleman Regency needs to be managed properly in accordance with the nature and characteristics.
\end{abstract}

Keywords: environmental health, household hazardous waste, impacts, toxic material.

\section{PENDAHULUAN}

Bahan berbahaya dan beracun (B3) adalah zat, energi, dan/atau komponen lain yang karena sifat, konsentrasi, dan/atau jumlahnya, baik secara langsung maupun tidak langsung, dapat mencemarkan dan/atau merusak lingkungan hidup, dan/atau membahayakan lingkungan hidup, 
kesehatan, serta kelangsungan hidup manusia dan makhluk hidup lain (Anonim, 2009). Limbah yang memiliki karakteristik mudah meledak, mudah terbakar, reaktif, beracun, infeksius dan/atau korosif termasuk limbah B3 (Anonim, 2014). Pemakaian produk-produk rumahtangga yang mengandung B3 pada akhir pemakaiannya (post consumer) akan menjadi sampah. Jenis sampah yang mengandung B3 dan/atau limbah B3 dikategorikan sebagai jenis sampah spesifik (Anonim, 2008), sedangkan jenis limbah/sampah rumahtangga yang mengandung B3 dan/atau limbah B3 sering disebut dengan istilah Sampah B3 Rumah Tangga atau SB3-RT (Anonim, $2012^{\mathrm{a}}$ ).

Beberapa contoh sampah B3 yang dihasilkan di rumahtangga antara lain sampah dari baterai, lampu listrik, elektronik, kemasan pestisida, pemutih pakaian, pembersih lantai, cat, kaleng bertekanan (aerosol), kemasan bahan bakar, sisa obat-obatan (farmasi), termometer air raksa dan jarum suntik. Bahan-bahan yang terkandung di dalam SB3-RT memiliki karakteristik yang dapat menimbulkan gangguan keselamatan dan kesehatan manusia serta pencemaran lingkungan. Sampai saat ini, kuantitas dan karakteristik SB3-RT yang dihasilkan di Kabupaten Sleman Provinsi Daerah Istimewa Yogyakarta belum pernah dikaji dan belum ada mekanisme pengelolaan sampah B3 rumahtangga.

Sampah B3 rumahtangga masih diperlakukan sama dengan sampah domestik sesuai pola yang dijalankan oleh pemerintah dan masyarakat. Data Kantor Lingkungan Hidup (KLH) Kabupaten Sleman Tahun 2013 menunjukkan bahwa persentase sampah yang diangkut dan dibuang ke TPA Piyungan melalui sistem pelayanan pemerintah $/$ swasta $($ pola perkotaan $)=11,85 \%$; yang dikelola masyarakat melalui kelompok pengelolaan sampah mandiri (pola mandiri) $=2,63 \%$; dan yang ditangani sendiri-sendiri oleh masyarakat (pola perdesaan) melalui cara yang tidak berwawasan lingkungan seperti dibuang ke sungai, dibakar dan/atau ditimbun di halaman rumah $=85,52 \%$. Penanganan SB3-RT yang dijalankan tersebut berpotensi menyebabkan pencemaran air, tanah, dan udara di lingkungan permukiman dan TPA. Sampah B3 rumahtangga berisiko terhadap keselamatan dan kesehatan bagi keluarga, masyarakat, petugas/pekerja, pemulung dan pengepul sampah.

Berdasarkan latar belakang tersebut, maka dapat dirumuskan permasalahan bahwa SB3-RT di Kabupaten Sleman sampai saat ini belum diketahui jenis, kuantitas dan karakteristik SB3-RT, serta belum dikelola sebagaimana mestinya. Apabila dibiarkan terus menerus maka SB3-RT berpotensi menimbulkan dampak negatif terhadap kesehatan dan lingkungan. Tujuan penelitian ini adalah untuk mengkaji timbulan, karakteristik dan aliran materi SB3-RT serta potensi dampak kesehatan lingkungan yang ditimbulkan.

\section{METODE PENELITIAN}

\section{Waktu dan Lokasi}

Pengumpulan SB3-RT dilakukan selama tiga puluh hari pada tanggal 21 Januari - 19 Februari 2012. Penelitian dilakukan pada 2 (dua) Kelompok Pengelolaan Sampah Mandiri (KPSM) yang berada di wilayah perkotaan Kabupaten Sleman yaitu KPSM Sukunan (Kecamatan Gamping) dan KPSM Minomartani (Kecamatan Ngaglik) dan 2 (dua) KPSM di wilayah perdesaan yaitu KPSM Senuko (Kecamatan Godean) dan KPSM Gandok-Kadilobo (Kecamatan Pakem). Responden di wilayah perdesaan memiliki karakteristik sebagai masyarakat agraris yaitu bermata-pencaharian sebagai petani dan buruh tani, sedangan di wilayah perkotaan bekerja di sektor non-agraris yaitu sebagai PNS, pegawai swasta, pensiunan, dan buruh bangunan.

\section{Bahan dan Alat}

Peralatan yang digunakan dalam penelitian ini meliputi kantong penampung SB3-RT, sarung tangan, masker, timbangan, spektrometer untuk pemeriksaan logam berat metode AAS, daftar pertanyaan, alat perekam, kamera, catatan dan alat tulis. Bahan yang dikaji dalam penelitian ini adalah semua jenis SB3-RT yang dihasilkan oleh 120 keluarga selama 30 hari.

\section{Prosedur}

Langkah awal dalam penelitian ini adalah memilih 120 sampel rumahtangga secara simple random sampling, membagikan kantong penampung SB3-RT, mengumpulkan dan identifikasi jenis SB3RT, menimbang SB3-RT sesuai jenisnya per rumahtangga, memeriksa kadar logam berat pada baterai dan lampu fluorescent bekas, menganalisis karakteristik SB3-RT berdasarkan referensi dan hasil penelitian lain. Langkah selanjutnya adalah mengkaji aliran materi SB3-RT pada pola-pola penanganan sampah yang berjalan di Kabupaten Sleman dan mengkaji potensi dampak kesehatan lingkungan yang ditimbulkan SB3-RT.

\section{HASIL DAN PEMBAHASAN}

\section{Timbulan Sampah B3 Rumahtangga}

Kuantitas SB3-RT yang dihasilkan oleh 120 rumahtangga dengan jumlah jiwa 486 orang selama 30 hari adalah sebanyak 568 item dan berat $35.544 \mathrm{~g}$ yang disajikan pada Tabel 1. 
Tabel 1. Timbulan sampah B3 rumahtangga di Kabupaten Sleman.

\begin{tabular}{lrrrr}
\hline \multirow{2}{*}{ Jenis sampah B3 rumahtangga } & \multicolumn{2}{c}{ Jumlah } & \multicolumn{2}{c}{ Berat } \\
\cline { 2 - 5 } & Item & \multicolumn{1}{c}{ gram } & \% \\
\hline Baterai bekas & 122 & 24,65 & 5938 & 16,71 \\
Lampu listrik bekas & 140 & 21,48 & 6425 & 18,08 \\
Elektronik bekas & 49 & 8,63 & 8854 & 24,91 \\
Bekas kemasan cat & 35 & 6,16 & 2278 & 6,41 \\
Bekas kemasan pestisida & 22 & 3,87 & 2169 & 6,10 \\
Sisa dan kemasan obat/medis & 66 & 11,62 & 2415 & 6,79 \\
Bekas kemasan gas dan bahan bakar & 39 & 6,87 & 1882 & 5,29 \\
Kemasan produk perawatan diri dan kecantikan & 65 & 11,44 & 3894 & 10,96 \\
Kemasan produk pemeliharaan rumah & 30 & 5,28 & 1689 & 4,75 \\
\hline Jumlah & 568 & 100 & 35544 & 100,00 \\
\hline Rata-rata timbulan & 0,04 item/org/hari & \multicolumn{4}{c}{ g/org/hari } \\
\hline
\end{tabular}

Sumber: Data primer terolah.

Dilihat dari kuantitasnya, timbulan SB3-RT di Kabupaten Sleman tersebut lebih tinggi dibandingkan rata-rata timbulan di Kecamatan Jambangan, Surabaya yaitu 1,6 g/orang/hari (Mustikawati dan Trihadiningrum, 2009), tetapi lebih rendah dibandingkan Kota Padang dengan rata-rata sebesar $0,004 \mathrm{~kg} / \mathrm{orang} / \mathrm{hari}$ dalam satuan berat (Ruslinda dan Yustisia, 2013). Timbulan SB3RT Kabupaten Sleman juga lebih rendah dibandingkan negara-negara lain, misalnya: Jepang $=5,56 \mathrm{~g} /$ orang $/$ hari dan Denmark $=13,89$ g/orang/hari (Benitez dkk., 2013). Di Amerika Serikat rata-rata setiap rumahtangga menghasilkan lebih dari 20 pounds (sekitar $9,07 \mathrm{~kg}$ ) per tahun atau sekitar 24,85 g/keluarga/hari (Anonim, 1993). Di Belgia, Luksemburg dan Belanda, timbulan SB3-RT antara 1,3 - 3,5 kg/orang/tahun atau sekitar 3,569,59 g/orang/hari. Meskipun kecil, tetapi risiko yang ditimbulkan SB3-RT tidak boleh diabaikan (Anonim, 2012 ${ }^{\mathrm{b}}$ ).

Rata-rata timbulan SB3-RT di Kabupaten Sleman adalah $0,49 \%$ dari rata-rata jumlah sampah yang dihasilkan $(0,5 \mathrm{~kg} /$ orang/hari $)$. Persentase tersebut lebih tinggi dibandingkan SB3-RT di TPA Piyungan yaitu sebesar 0,38\% (Gunamantha, 2010), tetapi lebih rendah dari Kota Padang yaitu sebesar 1,09\% (Ruslinda dan Yustisia, 2013). Persentase SB3-RT di Kabupaten Sleman lebih rendah dibandingkan negara-negara lain, misalnya: Swiss = $0,50 \%$; Inggris $=0,90 \%$, Hungaria $=0,70 \%$ (Gendebien dkk., 2002), Mexico $=1,60 \%$ (Buenrostro-Delgado dkk., 2008); dan Nepal = 1,00\% (Dangi dkk., 2011). Data dari berbagai negara di dunia menunjukkan bahwa rata-rata kuantitas SB3-RT adalah 1\% dari sampah kota (Gendebien dkk., 2002).

Perbedaan timbulan SB3-RT di berbagai lokasi kemungkinan berkaitan dengan berbagai faktor, yaitu metode pengambilan sampel dalam penelitian, penetapan jenis SB3-RT (identifikasi), dan strategi pengelolaan sampah pada suatu daerah (Benitez dkk., 2013). Metode pengambilan sampel yang dilakukan oleh Gunamantha (2010) adalah mengambil sampel sampah yang dibuang ke TPA Piyungan, kemudian dipilah dan dihitung SB3-RT, sedangkan dalam penelitian ini sampah diperoleh secara langsung dari rumahtangga. Sebelum diangkut ke TPA, sebagian jenis SB3-RT yang bernilai jual akan dipungut oleh pemulung dan/atau petugas pengangkutan, sehingga dapat mengurangi kuantitas sampah yang sampai di TPA. Timbulan SB3-RT yang lebih tinggi, kemungkinan disebabkan karena SB3-RT yang dikumpulkan tidak hanya limbah B3 padat tetapi termasuk limbah cair (minyak, oli bekas). Di samping itu SB3-RT tidak hanya yang dihasilkan selama periode pengamatan penelitian, tetapi termasuk akumulasi SB3-RT yang dihasilkan sebelumnya. Dalam penelitian ini, rumahtangga yang menjadi sampel penelitian sudah disosialisasi dan dikondisikan agar SB3-RT yang dimasukkan ke dalam tempat penyimpanan hanya SB3-RT yang dihasilkan hanya selama periode yang ditentukan.

\section{Karakteristik Sampah B3 Rumahtangga Baterai bekas}

Jenis baterai yang ditemukan dalam penelitian ini terdiri atas: $90,98 \%$ baterai rumah sekali pakai dengan tipe AAA, AA, C, D, 9 Volt dan 12 Volt; $1,68 \%$ baterai kancing (button baterry); 7,38\% baterai isi ulang dan $0,82 \%$ bateri kendaraan bermotor (aki). Jenis baterai rumah sekali pakai yang paling banyak adalah AA $(45,08 \%)$ dengan kadar logam berat tersaji pada Tabel 2 .

Kandungan logam berat pada pemeriksaan baterai AA dalam penelitian ini secara umum lebih tinggi dibandingkan Almeida dkk., (2006), kecuali unsur $\mathrm{Pb}$ dan $\mathrm{Zn}$ memiliki kandungan lebih rendah. Jenis unsur logam berat dengan konsentrasi tinggi yang ditemukan di dalam baterai AA bekas adalah Zn (pada katoda yaitu 7.570,401 $\mu \mathrm{g} / \mathrm{g}$ dan pada anoda sebesar 1.717,903 $\mu \mathrm{g} / \mathrm{g}$ ), atau lebih rendah 
Tabel 2. Kandungan logam berat pada baterai AA bekas.

\begin{tabular}{crrrr}
\hline Komponen & \multicolumn{3}{c}{ Hasil pemeriksaan laboratorium $(\mu \mathrm{g} / \mathrm{g})$} & Penelitian Almeida dkk., $2006(\mu \mathrm{g} / \mathrm{g})$ \\
\cline { 2 - 5 } Logam & Katoda & Anoda & Katoda & Anoda \\
\hline $\mathrm{Pb}$ & 9,79 & 12,45 & $<11$ & 42 \\
$\mathrm{Hg}$ & $\mathrm{TTD}$ & $\mathrm{TTD}$ & TTD & TTD \\
$\mathrm{Cd}$ & 0,15 & 0,73 & TTD & TTD \\
$\mathrm{Ni}$ & 40,97 & 76,54 & 18 & TTD \\
$\mathrm{Cu}$ & 34,62 & 8,13 & TTD & TTD \\
$\mathrm{Zn}$ & $7.570,41$ & $1.717,90$ & 9.000 & 792.000 \\
$\mathrm{Co}$ & 10,260 & TTD & 27 & TTD \\
$\mathrm{Cr}$ & 9,66 & 5,66 & 7 & TTD \\
\hline
\end{tabular}

Keterangan : TTD $=$ tidak terdeteksi atau di bawah batas deteksi. Sumber: Data primer terolah.

dibandingkan hasil pemeriksaan yang dilakukan oleh Almeida dkk., (2006) yaitu pada bagian katoda $9.000 \mu \mathrm{g} / \mathrm{g}$ dan anoda $7,92.10^{5} \mu \mathrm{g} / \mathrm{g}$. Sementara kandungan $\mathrm{Hg}$ sama-sama tidak terdeteksi di dalam baterai AA bekas. Baterai isi ulang mengandung Co, $\mathrm{Cr}, \mathrm{Ni}, \mathrm{Zn}, \mathrm{Al}$ (Nnorom dan Osibanjo, 2009), sedangkan baterai kancing mengandung $\mathrm{Zn}, \mathrm{Pb}, \mathrm{Cd}$ dan Hg (Anonim, 2014). Baterai otomotif (lead-acid baterry) mengandung berbagai unsur logam berat antara lain $\mathrm{Hg}, \mathrm{Pb}, \mathrm{Cd}, \mathrm{Cr}, \mathrm{Zn}$ dan $\mathrm{Ni}$ (Rina dan Wardani, 2005).

\section{Lampu listrik bekas}

Jenis lampu listrik yang ditemukan dalam penelitian ini terdiri atas: $47,86 \%$ fluorescent jenis CFL (Compact Fluorescent Lamps) atau Lampu Hemat Energi (LHE); 13,57\% fluorescent jenis TL (Tube Luminescent); 37,86\% lampu pijar; 0,71\% lampu LED (Light Emitting Diode). Jenis lampu listrik yang mengandung bahan berbahaya dan beracun adalah lampu fluorescent baik tipe CFL maupun TL. Kandungan logam berat berbahaya pada jenis lampu CFL dan TL dapat dilihat pada Tabel 3.

Merkuri ( $\mathrm{Hg})$ tidak terdeteksi pada lampu CFL, namun karena salah satu bahan utama yang dimasukkan dalam lampu CFL adalah merkuri, maka penanganannya harus disamakan dengan jenis SB3-RT yang mengandung merkuri. Jenis logam berat yang terkandung di dalam lampu CFL dari kadar tertinggi secara berturut-turut adalah $\mathrm{Al}, \mathrm{Cu}$, $\mathrm{Ni}, \mathrm{Pb}$, dan Zn. Salah satu bagian lampu TL yang harus diwaspadai adalah kaca, karena ditemukan merkuri (Hg) walaupun kadarnya sangat kecil. Merkuri ( $\mathrm{Hg}), \mathrm{Pb}$, dan Ni termasuk jenis logam berat kategori major metals, sedangkan $\mathrm{Zn}$ dan $\mathrm{Cu}$ termasuk jenis logam-logam esensial. Kandungan jenis-jenis logam berat tersebut berpotensi menimbulkan keracunan (Sembel, 2015).

\section{Sampah elektronik}

Sampah kabel merupakan jenis sampah elektronik yang paling banyak (masing-masing $20,97 \%$ ), sedangkan dilihat dari beratnya ternyata monitor TV bekas yang paling besar $(41,97 \%)$. Bahan-bahan kimia dalam pembuatan kabel meliputi: antimony, $\mathrm{Ba}, \mathrm{Cr}, \mathrm{Pb}, \mathrm{DEHP}$ dan $\mathrm{Zn}$ (Harriman, 2002). Bahan-bahan berbahaya dan beracun yang umumnya terkandung di dalam sampah elektronik sebagaiman tersaji pada Tabel 4.

\section{Kemasan cat}

Jenis bekas kemasan cat yang ditemukan terdiri atas: $45,45 \%$ cat berpelarut air (latex); 27,27\% cat semprot (aerosol); 13,64\% cat solvent; dan 13,64\% kemasan pelarut cat. Cat latex menggunakan pewarna yang mengandung kromium (Cr) dan timbal $(\mathrm{Pb})$, sedangkan cat solvent mengandung pewarna yang mengandung $\mathrm{Pb}$ dan $\mathrm{Hg}$ (Galvin dan Dickey, 2008). Pewarna cat umumnya menggunakan bahan yang mengandung logam berat

Tabel 3. Kandungan logam berat pada lampu fluorescent jenis CFL dan TL.

\begin{tabular}{lccc}
\hline \multirow{2}{*}{ Komponen } & Parameter & \multicolumn{2}{c}{ Rata-rata $\pm \mathrm{SD}(\mu \mathrm{g} / \mathrm{g})$} \\
\cline { 3 - 4 } & & $2.392,54 \pm 41,56$ & Lampu TL \\
\hline Kaca & $\mathrm{Pb}$ & Tidak terdeteksi & $191,69 \pm 19.57$ \\
Fitting (dasar) & $\mathrm{Hg}$ & $388.475,90 \pm 11.144,73$ & $0,29 \pm 0.15$ \\
& $\mathrm{Al}$ & $31,14 \pm 0.53$ & Tidak dukur \\
& $\mathrm{Zn}$ & Tidak diukur & $171,95 \pm 6,16$ \\
Filamen (ballast) & $\mathrm{Cu}$ & Tidak diukur & $1.280,86 \pm 16,60$ \\
& $\mathrm{Ni}$ & $185.431,80 \pm 984.85$ & $97,76 \pm 4,10$ \\
& $\mathrm{Cu}$ & $71.158,68 \pm 170.80$ & $224.534,25 \pm 4.945,70$ \\
& $\mathrm{Ni}$ & $431,68 \pm 23.87$ & $46.340,64 \pm 602,33$ \\
\hline
\end{tabular}

Sumber : Hasil pemeriksaan laboratorium dengan metode AAS. 
Tabel 4. Jenis B3 yang terkandung di dalam sampah elektronik.

\begin{tabular}{ll}
\hline \multicolumn{1}{c}{ Jenis kandungan B3 } & \multicolumn{1}{c}{ Komponen elektronik yang mengandung B3 } \\
\hline Antimony (Sb) & $\begin{array}{l}\text { kaca monitor TV/komputer (CRT), plastik kerangka (rumah) pada komputer, } \\
\text { campuran pateri (solder) pada kabel }\end{array}$ \\
Arsenic (As) & $\begin{array}{l}\text { Light Emitting Diodes (LED) } \\
\text { busi,CRT }\end{array}$ \\
Barium $(\mathrm{Ba})$ & Kotak power, motherboards \\
Beryllium $(\mathrm{Be})$ & PCB, plastic kerangka (rumah) elektronik dan kabel \\
BFRs & chip semikonduktor, detector infra merah, tinta dan toner pada printer \\
Cadmium $(\mathrm{Cd})$ & plastik rumah komputer, kabel, hard discs, pigmen warna \\
Chromium $\mathrm{VI}(\mathrm{Cr} \mathrm{VI})$ & pateri (solder), CRT, kabel, PCB, tabung fluorescent \\
Lead $(\mathrm{Pb})$ & backlight bulbs/lamps, flat panel displays, saklar dan thermostat \\
Mercury (Hg) & rumah komputer, CRT dan PCB \\
Nickel $(\mathrm{Ni})$ & mesin fotokopi (tipe lama) \\
Selenium $(\mathrm{Se})$ & kondensor, transformer dan cairan penghantar panas \\
PCBs & monitor, keyboard, kabel, dan plastik rumah computer \\
PVC & Sumber : Pucket dan Smith (2002); Kiddee dkk. (2013).
\end{tabular}

berbahaya seperti $\mathrm{Pb}, \mathrm{Cd}, \mathrm{Cr}$ dan $\mathrm{Zn}$ (Bowen, 1998; Anonim, 2000). Bekas kemasan pelarut cata yang masih mengandung bahan-bahan seperti petroleum distillates, white spirit, butanol, xylen, diaseton alkohol bersifat mudah terbakar dan beracun (Galvin dan Dickey, 2008; Bowen, 1998). Kemasan cat semprot (aerosol) yang masih mengandung propana dan butana dapat meledak dan berpotensi menimbulkan kebakaran (Galvin dan Dickey, 2008).

\section{Kemasan pestisida}

Jenis sampah pestisida yang paling banyak ditemukan adalah kemasan insektisida aerosol $(50,00 \%)$, diikuti kemasan insektisida padat/cair $(27,27 \%)$ dan pestisida pertanian $(22,73 \%)$. Kandungan bahan aktif pada pestisida antara lain: bendiocarb, pyrethroids, dichlofluanid, atrazine, simazine, acid herbicides, organokhlorin, organo fosfat, arsenik, warfrin, strychnine dan brodifacoum. Kemasan yang mengandung sisa-sisa bahan aktif tersebut termasuk kategori sangat beracun (Galvin dan Dickey, 2008).

\section{Sampah medis dan farmasi}

Jenis sampah medis yang ditemukan dalam penelitian ini terdiri atas: $56,97 \%$ sisa obat tablet/padat/bubuk; 37,88\% kemasan obat cair; $12,12 \%$ kemasan obat luar; $1,52 \%$ jarum suntik; dan $1,52 \%$ termometer air raksa. Sampah obat-obatan dan farmasi termasuk kategori-3 di dalam klasifikasi sampah medis berbahaya (Anonim, 2011). Bekas jarum suntik berpotensi mengandung bibit penyakit menular seperti hepatitis $\mathrm{B}$, hepatitis $\mathrm{C}$ dan HIV/AIDS. Termometer mengandung $\mathrm{Hg}$ yang dapat terakumulasi di dalam sedimen dan dapat berubah menjadi metil merkuri yang sangat beracun. Merkuri yang menguap dapat bertahan di atmosfer selama satu tahun sehingga dapat masuk ke dalam tubuh manusia melalui pernafasan (Anonim, 2011).

\section{Kemasan bahan bakar}

Kemasan produk-produk bahan bakar yang ditemukan terdiri atas: $74,36 \%$ korek api gas; $20,51 \%$ kemasan oli bekas; dan 5,13\% tabung bahan bakar gas (refill). Sebanyak 5 dari 29 buah korek api $(17,24 \%)$ masih mengandung sisa bahan, terutama korek api yang mengalami kerusakan pada roda pemantik api. Bekas kaleng atau tabung gas kecil mengandung bahan-bahan yang mudah terbakar dan meledak (Galvin dan Dickey, 2008).

\section{Sampah produk perawatan diri dan kecantikan}

Jenis sampah kelompok ini didominasi oleh bekas kemasan parfum aerosol $(53,85 \%)$. Bekas kaleng parfum aerosol berpotensi menimbulkan kebakaran, ledakan dan menyebabkan terjadinya iritasi pada mata dan kulit karena mengandung metilen klorida, asam nitrat, o-fenil fenol, propana, trikloroetana. Bekas kemasan pemutih pakaian yang dihasilkan rumahtangga sebesar $24,61 \%$ dan sisanya $(21,54 \%)$ adalah kosmetik, pewarna kuku dan rambut. Bahan pemutih mengandung sodium hipoklorit atau hidrogen peroksida, dan berpotensi menimbulkan keracunan, korosi, dan iritasi pada mata, kulit dan membran mukosa (Bowen, 1998).

\section{Sampah produk pemeliharaan rumah}

Jenis sampah dari kegiatan pemeliharaan rumah meliputi: $61,87 \% \%$ kemasan pembersih (lantai, kamar mandi, WC); 25,46\% kemasan pewangi ruang aerosol; dan $12,67 \%$ lem sintetis bekas (pipa, plastik, logam, serbaguna). Pembersih mengandung asam sitrat, natrium hipoklorit, asam klorida, asam fosfat, asam oksalat, senyawa 
surfaktan, dietil etil benzil klorida, hidrogen klorida, asam sulfat, asam laktat dan kalsium hipoklorit sehingga dapat menimbulkan korosi, keracunan dan iritasi pada mata, kulit dan membran mukosa. Fenol pada pembersih bersifat sangat beracun dan mudah terbakar serta dapat menimbulkan gangguan saluran pernafasan, sistem peredaran darah dan jantung. Kemasan pewangi ruangan (aerosol) mengandung formaldehid, isobutana, propana dan metilen klorida yang bersifat racun, mudah terbakar, mudah meledak dan menimbulkan iritasi pada mata dan kulit. Bekas lem sintetis mengandung sisa bahan xylene atau toluene yang bersifat mudah terbakar dan beracun (Bowen, 1998).

\section{Aliran materi SB3-RT Saat Ini (Kondisi Eksisting)}

Pola penanganan sampah yang dijalankan masyarakat mempengaruhi perjalanan materi (material flow) sampah beserta bahan berbahaya beracun yang terkandung di dalamnya. Aliran materi SB3-RT di Kabupaten Sleman tidak dapat dilepaskan dari peran sektor informal (pemulung dan pengepul sampah) yang memungut beberapa jenis SB3-RT yang berharga dan menyerahkan kepada pemanfaat (pabrik). Semakin banyak kuantitas SB3RT yang dipungut oleh pemulung dan/atau pengepul, maka semakin sedikit jumlah sampah yang dibuang ke lingkungan.

Berdasarkan estimasi timbulan SB3-RT di Kabupaten Sleman pada tahun 2013 sebesar 2,81 ton/hari, maka keberadaan sektor informal dapat mengurangi jumlah SB3-RT yang dibuang ke lingkungan dengan neraca timbulan SB3-RT sebagaimaa tersaji pada Tabel 5 .

Berdasarkan kuantitas SB3-RT yang dibuang ke lingkungan, maka jenis SB3-RT yang paling tinggi adalah sampah baterai $(81,39 \%)$ dan yang paling rendah adalah bekas kemasan cat $(3,33 \%)$. Menurut pola penanganan sampah yang selama ini dijalankan di Kabupaten Sleman, maka persentase pengurangan SB3-RT dapat dilihat pada Gambar 1.

Kemampuan pengurangan SB3-RT oleh sektor informal dari persentase tertinggi adalah: pola mandiri (pengelolaan sampah berbasis masyarakat) $=85,71 \%$, pola perkotaan (penanganan melalui pelayanan pemerintah/swasta) $=80,30 \%$, dan pola perdesaan (tanpa pelayanan dan tidak menjalankan pengelolaan sampah mandiri) $=47,55 \%$.

\section{Potensi Dampak Negatif SB3-RT terhadap Kesehatan dan Lingkungan}

Potensi dampak kesehatan dan lingkungan yang ditimbulkan oleh sampah B3 rumahtangga dipengaruhi oleh kuantitas, karakteristik dan cara penanganannya (Conn, 1989). Semakin besar kuantitas SB3-RT yang dibakar sembarangan dan dibuang secara langsung ke lingkungan, semakin besar risiko terjadinya gangguan kesehatan dan pencemaran lingkungan. Karakteristik bahan-bahan yang terkandung dalam SB3-RT di Kabupaten Sleman mempengaruhi berbagai dampak kesehatan sebagaimana tersaji pada Tabel 6 .

Cara penanganan SB3-RT yang banyak dilakukan oleh masyarakat terutama yang tinggal di perdesaan atau di wilayah yang belum mendapatkan pelayanan adalah membakar, membuang ke badan air, pekarangan rumah, lahan-lahan kosong atau tempat pembuangan sampah ilegal di lingkungan sekitar tempat tinggal. Berdasarkan hasil observasi lapangan diperoleh hasil bahwa cara penanganan yang dijalankan oleh para penjamah SB3-RT belum memperhatikan aspek kesehatan dan keselamatan kerja. Sebagai misal, kegiatan menyimpan sampah B3 benda tajam (jarum suntik dan pecahan lampu listrik) masih dicampur dengan sampah domestik tanpa kemasan plindung (safety box), sehingga berpotensi menyebabkan cidera, keracunan dan penularan penyakit bagi petugas sampah. Perilaku pemulung dan pengepul (sektor informal) dalam memilah dan mengambil komponen SB3-RT yang

Tabel 5. Neraca timbulan dan pengurangan SB3-RT oleh sektor informal (kondisi eksisting).

\begin{tabular}{lcccc}
\hline \multicolumn{1}{c}{ Jenis SB3-RT } & $\begin{array}{c}\text { Jumlah timbulan } \\
\text { SB3-RT } \\
\text { (ton/hari) }\end{array}$ & $\begin{array}{c}\text { Jumlah } \\
\text { pengurangan } \\
\text { SB3-RT (ton/hari) }\end{array}$ & $\begin{array}{c}\text { Jumlah } \\
\text { SB3-RT tersisa } \\
\text { (ton/hari) }\end{array}$ & $\begin{array}{c}\text { Persentase } \\
\text { SB3-RT yang } \\
\text { dibuang (\%) }\end{array}$ \\
\hline Baterai & 0,47 & 0,087 & 0,38 & 81,39 \\
Lampu listrik & 0,51 & 0,246 & 0,26 & 51,56 \\
Elektronik & 0,70 & 0,619 & 0,08 & 11,56 \\
Kemasan cat & 0,18 & 0,174 & 0,01 & 3,33 \\
Kemasan pestisida & 0,17 & 0,107 & 0,06 & 37,78 \\
Sampah medis & 0,19 & 0,045 & 0,15 & 76,51 \\
Kemasan bahan bakar & 0,15 & 0,139 & 0,01 & 6,67 \\
Sampah kecantikan & 0,31 & 0,148 & 0,16 & 51,94 \\
Pemeliharaan rumah & 0,13 & 0,100 & 0,03 & 25,00 \\
\hline Jumlah & 2,81 & 1,66 & 1,15 & 40,93 \\
\hline
\end{tabular}

Sumber: Data primer terolah. 


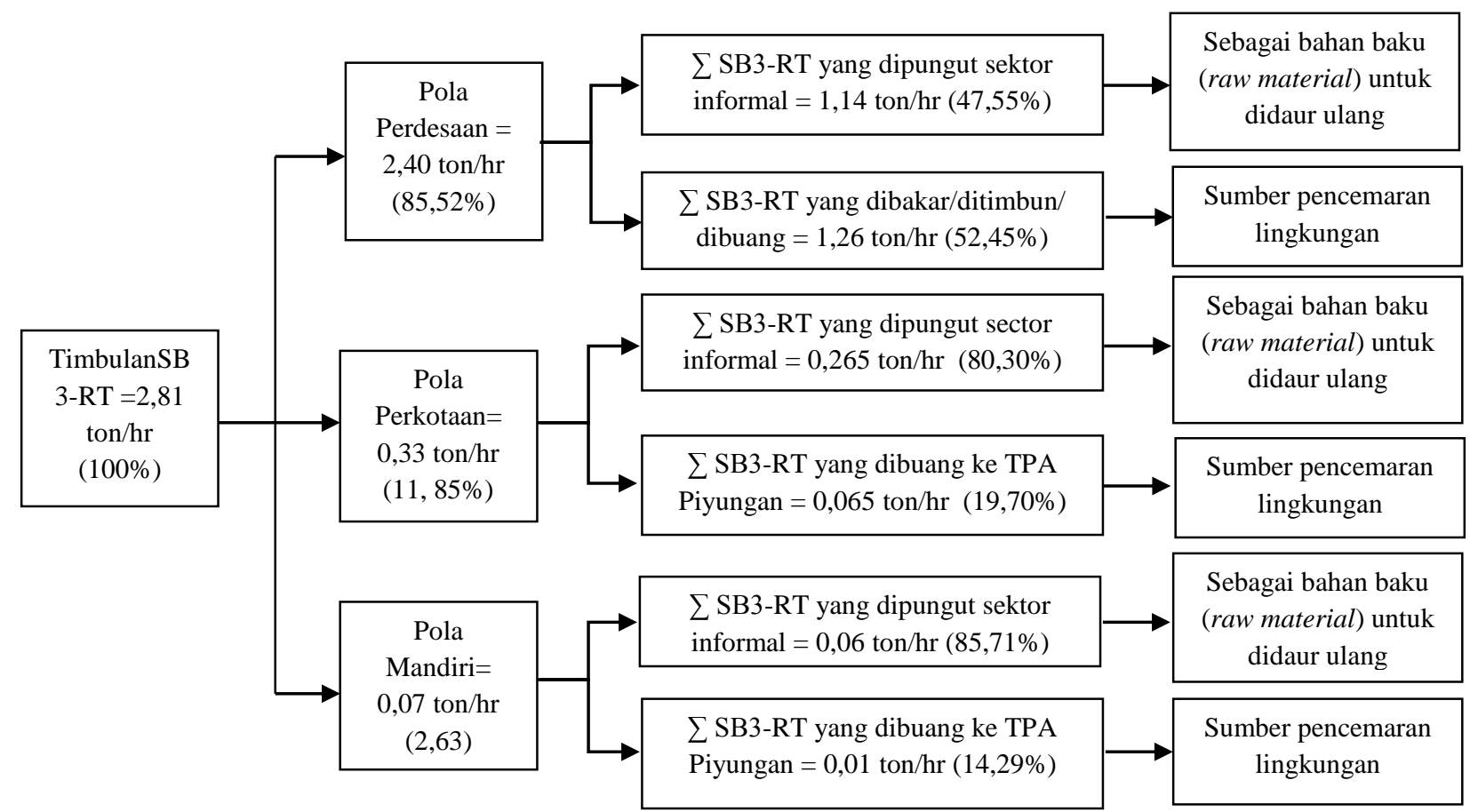

Gambar 1. Aliran materi SB3-RT berdasarkan pola penanganan sampah di Kabupaten Sleman.

Tabel 6. Potensi dampak berdasarkan karakteristik bahan yang terkandung di dalam SB3-RT

\begin{tabular}{|c|c|c|}
\hline Jenis SB3-RT & Bahan yang terkandung & Karakteristik dan dampak kesehatan \\
\hline Baterai & $\begin{array}{l}\text { Logam berat.: } \mathrm{As}, \mathrm{Cd}, \mathrm{Co} \\
\mathrm{Cr}, \mathrm{Cu}, \mathrm{Hg}, \mathrm{Mn}, \mathrm{Ni}, \mathrm{Pb}, \mathrm{Sb} \\
\mathrm{Zn} \text {, dan khusus aki } \\
\text { mengandung asam sulfat }\end{array}$ & $\begin{array}{l}\text { Beracun dan karsinogenik; menimbulkan kerusakan pada otak, sistem } \\
\text { saraf, ginjal, sistem reproduksi, paru, peredaran darah, kelainan kulit } \\
\text { dan kanker. Korosif dan reaktif (baterai); menyebabkan iritasi } \\
\text { (Kiddee dkk., 2013; Puckett dan Smith, 2002) }\end{array}$ \\
\hline Lampu listrik & $\mathrm{Hg}, \mathrm{Pb}, \mathrm{Cu}, \mathrm{Zn}, \mathrm{Ni}$ & $\begin{array}{l}\text { Karsinogenik dan neurotoksik, berefek akut dan kronis. (Galvin dan } \\
\text { Dickey, 2008) }\end{array}$ \\
\hline Sampah elektronik & $\begin{array}{l}\mathrm{Sb}, \mathrm{As}, \mathrm{Ba}, \mathrm{Be}, \mathrm{BFRs} \\
\mathrm{PBBs}, \mathrm{PBDEs}, \mathrm{Cd}, \mathrm{CFCs} \\
\mathrm{Cr}(\mathrm{VI}), \mathrm{Pb}, \mathrm{Hg}, \mathrm{Ni}, \mathrm{PCBs} \\
\text { PVC }\end{array}$ & $\begin{array}{l}\text { Beracun, karsinogenik dan kronik; menyebabkan penyakit kulit, } \\
\text { berilikosis, kanker paru, pembengkakan otak, otot lemah, kerusakan } \\
\text { jantung, hati dan limpa, otak, janin, gangguan hormone, ginjal dan } \\
\text { mata (Kiddee dkk., 2013) }\end{array}$ \\
\hline Kemasan cat & $\begin{array}{l}\mathrm{Cd}, \mathrm{Pb}, \mathrm{Cr}, \mathrm{Zn} \text { (pewarna); } \\
\text { minyak distillat, mineral } \\
\text { spirits; isobuti propane }\end{array}$ & $\begin{array}{l}\text { Mudah terbakar (solven), mudah meledak (aerosol), beracun; berefek } \\
\text { kronis; menyebabkan penyakit kronis terutama oleh logam berat } \\
\text { (Galvin dan Dickey, 2008) }\end{array}$ \\
\hline Kemasan pestisida & $\begin{array}{l}\text { Piretroid (metofluthrin, } \\
\text { pralethrin, d-alethrin); } \\
\text { organofosfat; karbamat }\end{array}$ & $\begin{array}{l}\text { Sangat beracun, mudah meledak (aerosol); berefek akut dan kronis; } \\
\text { organofosfat dan karbamat: menghambat enzim kolinesterase dan } \\
\text { gangguan system saraf pusat; piretroid : kelainan wajah, pusing, sakit } \\
\text { kepala, kelelahan, muntah, } \\
\text { (Reigart dan Roberts, 1999) }\end{array}$ \\
\hline $\begin{array}{l}\text { Sampah medis } \\
\text { dan farmasi }\end{array}$ & $\begin{array}{l}\text { Bahan kimia beracun; } \\
\text { patogen; benda tajam,; } \mathrm{Hg} \text {; } \\
\text { obat kadaluarsa }\end{array}$ & $\begin{array}{l}\text { Beracun (obat kadaluarsa dan termometer): berefek akut dan kronis, } \\
\text { meyebabkan keracunan; } \\
\text { Infeksius (jarum suntik): cidera dan menularkan penyakit hepatitis B, } \\
\text { C, HIV/AIDS) (Galvin dan Dickey, 2008; Anonim, 2011; Oyewole } \\
\text { dkk., 2014) }\end{array}$ \\
\hline $\begin{array}{l}\text { Kemasan bahan } \\
\text { bakar }\end{array}$ & $\begin{array}{l}\text { Bahan bakar gas, propana, } \\
\text { minyak }\end{array}$ & $\begin{array}{l}\text { Mudah meledak dan mudah terbakar; menyebabkan ledakan dan } \\
\text { kebakaran (Galvin dan Dickey, 2008) }\end{array}$ \\
\hline $\begin{array}{l}\text { Sampah produk } \\
\text { perawatan diri dan } \\
\text { kecantikan }\end{array}$ & $\begin{array}{l}\text { metilen klorida, asam nitrat, } \\
\text { o-fenil fenol, propana, } \\
\text { trikloroetana atau trikloro- } \\
\text { etilen; } \mathrm{Pb} \text {; natrium atau } \\
\text { peroksida hipoklorida }\end{array}$ & $\begin{array}{l}\text { Beracun, mudah meledak (aerosol), mudah terbakar, reaktif; } \\
\text { menyebabkan iritasi mata dan membran mukosa (sodium \& kalsium } \\
\text { hipoklorit). Larutan hipoklorit }+ \text { larutan asam atau amonia } \\
\text { menghasilkan gas klorin atau kloramin yang menyebabkan iritasi dan } \\
\text { keracunan paru-paru (Anonim, 2000) }\end{array}$ \\
\hline $\begin{array}{l}\text { Sampah produk } \\
\text { pemeliharaan } \\
\text { Rumah }\end{array}$ & $\begin{array}{l}\text { formaldehida, natrium } \\
\text { hipochorida, fenol, dietilen } \\
\text { glikol, asam klorida. }\end{array}$ & $\begin{array}{l}\text { Beracun, karsinogenik dan korosif; menyebabkan iritasi; luka bakar, } \\
\text { kerusakan saluran pernafasan dan jantung, system saraf pusat, ginjal } \\
\text { dan hati, iritasi kulit, mata. (Anonim, 2000) }\end{array}$ \\
\hline
\end{tabular}


berharga tanpa menggunakan sarung tangan, masker dan sarana yang memadai sehingga berpotensi cidera dan terpapar zat-zat berbahaya beracun (Anonim, 2011).

Secara umum masyarakat masih membakar SB3-RT secara terbuka bersama sampah domestik. Gas beracun yang dihasilkan dari pembakaran SB3RT dapat berupa asam klorida $(\mathrm{HCl})$, formaldehid, dioksin, hexchlorobenzene (HCB), logam berat, $\mathrm{CO}$ dan partikulat lainnya. $\mathrm{HCl}$ menyebabkan penumpukan cairan di paru-paru dan ulserasi pada saluran pernapasan. Formaldehid mengakibatkan mata berair, sensasi terbakar di mata dan tenggorokan, mual, kesulitan bernafas, ruam kulit dan kanker. Dioksin adalah senyawa yang sangat beracun, bersifat karsinogenik dan dapat menimbulkan gangguan hormon, dapat masuk ke janin, dan terakumulasi pada tanaman, binatang dan manusia (Anonim, 2001; Belliveau dan Lester, 2004).

Pembakaran, pembuangan atau penimbunan SB3-RT yang mengandung logam berat bersama sampah domestik di lingkungan permukiman dan TPA dapat menimbulkan masalah kesehatan masyarakat sekitar sebagaimana yang terjadi di China, India dan Ghana (Kiddee dkk., 2013). Anakanak yang tinggal dekat area daur ulang sampah elektronik di China memiliki kadar $\mathrm{Pb}$ dan $\mathrm{Cd}$ yang tinggi dalam darahnya (Huo dkk., 2007; Zheng dkk., 2008). Kadar PBB, PBD, PCB, $\mathrm{Cu}$ dan $\mathrm{Pb}$ pada rambut dan kulit kepala juga lebih tinggi dibandingkan orang yang tinggal di luar area (Zhao dkk., 2008, Wang dkk., 2009). Konsentrasi Cu, Sb dan Bi pada rambut pekerja daur ulang sampah elektronik di India lebih tinggi dibandingkan yang bukan pekerja (Ha dkk., 2009). Kadar Fe, Sb dan Pb pada urine pekerja daur ulang sampah elektronik di Ghana juga lebih tinggi daripada yang bukan pekerja (Asante dkk., 2012). Logam berat yang tercampur dengan sampah organik dalam jangka waktu tertentu akan mengalami leaching dan menghasilkan lindi (leachate) yang mengandung logam berat sehingga berpotensi mencemari tanah atau air dan selanjutnya masuk rantai makanan ke tanaman, binatang dan akhirnya ke dalam tubuh manusia (Olafisoye dkk., 2013). TPA yang digunakan untuk membuang semua jenis sampah termasuk SB3-RT secara umum mengandung berbabagi unsur logam berat, senyawa alifatik terhalogenasi, hidrokarbon aromatik, senyawa fenolik dan pestisida di dalam lindinya (Christensen dkk, 2001; Kjeldsen dkk, 2002; Isidori dkk., 2003). Keberadaan bahan-bahan pencemar yang berasal dari SB3-RT di dalam leachate TPA berpotensi mencemari lingkungan (tanah dan air) dan membahayakan kesehatan masyarakat sekitar TPA.

\section{KESIMPULAN}

Timbulan SB3-RT di Kabupaten Sleman pada tahun 2013 sebesar 2,81 ton/hari atau 2,44 g/orang/hari dan lebih tinggi dibandingkan rata-rata timbulan di Padang, tetapi lebih rendah dibandingkan rata-rata timbulan SB3-RT di dunia (1\%). SB3-RT yang dihasilkan di Kabupaten Sleman memiliki semua karakteristik sebagai limbah B3 yaitu mudah meledak, mudah menyala, korosif, infeksius, rekatif dan beracun, sehingga berpotensi menimbulkan keracunan akut dan kronis; kerusakan dan kelainan organ tubuh; gangguan sistem tubuh; penyakit degeneratif; penularan penyakit menular; kecelakaan; kecacatan; dan kematian.

Sektor informal (pemulung dan pengepul) sangat berperan dalam mengurangi jumlah SB3-RT yang dibuang ke lingkungan dan mempengaruhi aliran materi SB3-RT sesuai pola penanganan sampah yang berjalan. Sistem pengelolaan sampah mandiri memiliki kemampuan terbesar dalam mengurangi potensi pencemaran lingkungan di Kabupaten Sleman.

\section{DAFTAR PUSTAKA}

Almeida, M.F., Xara, S.M., Delgado, J., dan Costa, C.A, 2006. Characterization of Spent AA Household Alkaline Batteries. Waste Management, 26:466-476.

Anonim, 1993. Household Hazardous Waste Management: A Manual for One-Day Community Collection Programs. EPA530-R92-026, August 1993, US-EPA

Anonim, 2000. Best Management Practices Resource Guide, Chapter 1 : Household Hazardous Waste. Georgia: Region 4 DoD Pollution Prevention Partnership, US-EPA.

Anonim, 2001. Exposure and Human Health Reassessment of 2,3,7,8 Tetrachlorodibenzop-Dioxin (TCDD) and Related Compounds, Part I: Estimating Exposures to Dioxin-Like Compounds, Volume 2: Sources of DioxinLike Compounds in the United States. September 2000. Available at http://www.epa.gov/ncea/pdfs/dioxin/part1/v olume2.

Anonim, 2008. Undang-undang Republik Indonesia Nomor 18 Tahun 2008 tentang Pengelolaan Sampah, Jakarta.

Anonim, 2009. Undang-undang Republik Indonesia Nomor 32 Tahun 2009 tentang Perlindungan dan Pengelolaan Lingkungan Hidup, Jakarta.

Anonim, 2011. Medical Waste Management Reference. International Committee of the Red Cross (ICRC), Geneva. 
Anonim, 2012a . Peraturan Daerah Provinsi DIY Nomor 02 Tahun 2012 tentang Pengelolaan Limbah Bahan Berbahaya dan Beracun (B3), Yogyakarta.

Anonim, 2012 . Management of Household Hazardous Waste, Waste Management Policy \& Procedure Document. London Borough of Lambeth, London.

Anonim, 2014. Peraturan Pemerintah Republik Indonesia Nomor 101 Tahun 2014 tentang Pengelolaan Limbah Bahan Berbahaya dan Beracun (B3), Jakarta.

Asante, K.A., Agusa, T., Biney, C.A., Agyekum, W.A., Bello, M., Otsuka, M., Itai, T., Takahashi, S., and Tanabe, 2012. Multi-Trace Element Levels and Arsenic Speciation in Urine of E-Waste Recycling Workers from Agbogbloshie, Accra in Ghana. Science of The Total Environment, 424:63-73.

Belliveau, M., dan Lester, S., 2004. PVC Bad News Comes in s The Poison Plastic, Health Hazards and the Looming Waste Crisis. Center for Health, Environment and Justice Environmental Health Strategy Center, Virginia.

Benitez, S.O, Virgen, Q.A., Gonzales, P.T., dan Sotelo, S.E.C., 2013. Household Hazardous Wastes as A Potential Source of Pollution: A Generation Study. Waste Management \& Research, 31(12):1279-1284.

Bowen, C.F., 1998. Household Hazardous Product and Hazardous Waste: A Summary for Consumer. Department of Agriculture and Extension Education, Pennsylvania.

Buenrostro-Delgado, O., Marquez-Benavides, L., dan Pinnete-Gaona, F., 2008. Consumption Patters and Household Hazardous Solid Waste Generation in Anurban Settlement in Mexico. Waste Management. 28: S2-S6.

Christensen, T.H., Kjeldsen, P., Bjerg, P.L., Jensen, D.L., Christensen, J.B., dan Baun, A., 2001. Biogeochemistry of Landfill Leachate Plumes. Appl Geochem, 16:659-718.

Conn, W.D., 1989. Managing Household Hazardous Waste. Journal of the American Planning Association, 55:192-203.

Dangi, M.B., Pretz, C.R., Urynowicz, M.A., Gerow, K.G. dan Reddy, J.M., 2011. Municipal Solid Waste Generation in Kathmandu, Nepal. Journal of Environmental Management, 92:240-249.

Galvin, D., dan Dickey, P., 2008. What Is Household Hazardous Waste, in Handbook on Household Hazardous Waste, edited by Amy D. Cabaniss, Government Institutes, Maryland, pp:1 37 .
Gendebien, A., Leavens, A., Blackmore, K., Godley, A., Lewin, K., Franke, B. dan Franke, A., 2002. Study on Hazardous Household Waste (HHW) with Main Emphasis on Hazardous Household Chemicals (HHC). WRc Ref: CO. 5089-2. Final Report, Brussels: European Commission - Directorate- General Environment.

Gunamantha, I.M., 2010. Pengembangan Model Life Cycle Assessment untuk Menganalisis Indikator Dampak Lingkungan dari Berbagai Alternatif Pengelolaan Sampah untuk Energi. Disertasi, Sekolah Pascasarjana Universitas Gadjah Mada Yogyakarta.

Ha, N.N., Agusa, T., Ramu, K., Tu, N.P.C., Murata, S., Bulbule, K.A., Parthasarty, P., Takashi, S., Subramanian, A., dan Tanabe., S., 2009. Contamintaion by Trace Elements as e-Waste Recycling Sites in Bangalore, India. Chemosphere, 76:9-15.

Harriman, L., 2002. Environmental, Health and Safety Issues in The Coated Wire And Cable Industry. Greiner Environmental, Inc. Massachusetts Toxics Use Reduction Institute, University of Massachusetts Lowell, One University Ave. Lowell.

Huo, X., Peng, L., Zheng, L., Qui, B., Zhang, B., Hand, D., dan Piao, Z., 2007. Elevated Blood Lead Levels of Children in Guiyu, an Electronic Waste Recycling Town in China. Environmental Perspectives, 115:1113-1117.

Isidori, M., Lavorgna, M., Nardelli, A., dan Parrella, A., 2003. Toxicity identification Evaluation of Leachates from Municipal Solid Waste Landfills: A Multispecies Approach. Chemosphere, 52:85-94.

Kiddee, P., Naidu, R., dan Wong, M.H, 2013. Electronic Waste Management Approaches: An Overview. Waste Management, 33:12371250.

Kjeldsen, P., Barlaz, M.A., Rooker, A.P., Baun, A., Ledin, A. dan Christensen, T.H., 2002. Present and Long-term Composition of MSW Landfill Leachate: A Review. Environ. Sci. Technol., 32:297-336.

Kusumadewi, S., Hartati, S., Harjoko, A., dan Wardoyo., 2006. Fuzzy Multi-Attribute Decision Makin (Fuzzy MADM). Graha Ilmu, Yogyakarta.

Mustikawati, Y.D.P dan Trihadiningrum, Y., 2009. Studi Pengelolaan Sampah B3 Permukiman di Kecamatan Jambangan Surabaya. Jurusan Teknik Lingkungan FTSP, Institut Teknologi Surabaya, Surabaya.

Nnorom, C., dan Osibanjo,O., 2009. Heavy Metal Characterization of Waste Portable 
Rechargeable Batteries Used in Mobile Phones. Int. J. Environ. Sci. Tech., 6(4):641650.

Olafisoye, O.B., Adefioye, B., and Osibote, O.A., 2013. Heavy Metal Contamination of Water, Soil and Plants Around An Electronic Waste Dumpsite. Pol. Journal Environment Study, 22(5):1431-1439.

Oyewole, A., Sapp, J., Wilson, B., and Oyewole, O. 2014. Potential Environmental Risks from Home Healthcare-Generated Municipal Solid Waste in Texas. International Journal of Business, Humanities and Technology, 4(3):612.

Puckett, J., dan Smith, T., 2002. Exporting Harm The High-Tech Trashing of Asia, In Coalition, S.V.T. (Ed.).

Reigart, J.R. dan Roberts, J.R., 1999. Recognition and Management of Pesticide Poisonings, Certification and Worker Protection Branch Field and External Affairs Division Office of Pesticide Programs U.S. Environmental Protection Agency.

Rina, T., dan Wardani, S., 2005. Analisis Logam Berat pada Sampel Sayuran dengan Metode Analisis Aktivasi Neutron. Prosiding Seminar Nasional Sains dan Teknik Nuklir, P3TKNBATAN Bandung, 14 -15 Juni 2005.
Ruslinda, Y., dan Yustisia, D., 2013. Analisis Timbulan dan Komposisi Sampah Bahan Berbahaya dan Beracun (B3) Rumah Tangga di Kota Padang Berdasarkan Tingkat Pendapatan, Jurnal Lingkungan Tropis, 7(1):21-30.

Slacks, R.J., Gronow, J.R., dan Voulvoulis, N., 2005. Household Hazardous Waste in Municipal Landfills: Contaminants in Leachate. Science of the Total Environment 337:119-137.

Sembel, D.T., 2015. Toksikologi Lingkungan: Dampak Pencemaran dari Berbagai Bahan Kimia dalam Kehidupan Sehari-hari, Andi Offset, Yogyakarta.

Wang, T., Fu., J., Wang, Y., Liao, C., Tao, Y., dan Jiang, G., 2009. Use of Scalp Hair as Indicator of Human Exposure to Heavy Metals in an Electronic Waste Recycling Area. Environmental Pollution, 157:2445-2451.

Zheng, I., Wu, K., Li, Y., Qi, Z., Han, D., Zhang, B., Gu, C., Chen, G., Liu, J., Chen, S., Xu, X., dan Huo, X., 2006. Blood Lead and Cadmium Levels and Relevant Factors among Children from an E-Waste Recycling Town in China. Environmental Research, 108:15-20. 